\title{
Author Correction: Synergy between the anthocyanin and RDR6/SGS3/DCL4 siRNA pathways expose hidden features of Arabidopsis carbon metabolism
}

\author{
Nan Jiang (1D, Aimer Gutierrez-Diaz (1), Eric Mukundi, Yun Sun Lee, Blake C. Meyers (1), Marisa S. Otegui (1) \& \\ Erich Grotewold (D)
}

Correction to: Nature Communications https://doi.org/10.1038/s41467-020-16289-3, published online 15 May 2020.

The original version of the Supplementary Information associated with this Article contained errors in Supplementary Figs. 8 and 10. In Supplementary Fig. 8, the axes and the grid lines were missing from all six panels. In panel d of Supplementary Fig. 10, the figure element linking the sequences to the gene structure diagram was missing. The HTML has been updated to include a corrected version of the Supplementary Information.

Published online: 14 October 2020

\footnotetext{
(c) (i) Open Access This article is licensed under a Creative Commons Attribution 4.0 International License, which permits use, sharing, adaptation, distribution and reproduction in any medium or format, as long as you give appropriate credit to the original author(s) and the source, provide a link to the Creative Commons license, and indicate if changes were made. The images or other third party material in this article are included in the article's Creative Commons license, unless indicated otherwise in a credit line to the material. If material is not included in the article's Creative Commons license and your intended use is not permitted by statutory regulation or exceeds the permitted use, you will need to obtain permission directly from the copyright holder. To view a copy of this license, visit http://creativecommons.org/licenses/by/4.0/.
}

(C) The Author(s) 2020 